\title{
Influence of Alpha Lipoic Acid Supplementation on Urinary Bladder Morphology of Diabetic Rats
}

\author{
Influencia de la Suplementación con Ácido Alfa Lipoico en \\ la Morfología de la Vejiga Urinaria de Ratas Diabéticas
}

\begin{abstract}
Lanna Beatriz Neves Silva Corrêa ${ }^{1}$; Cristiane Simões Coelho Britto Ramos ${ }^{1}$; Renato de Souza Abboud $^{\mathbf{1}}$; Ilma Cely de Amorim Ribeiro ${ }^{1}$; Reinaldo Ropke Junior ${ }^{1}$; Gilson Teles Boaventura ${ }^{2}$ \& Mauricio Alves Chagas ${ }^{1}$
\end{abstract}

CORRÊA, L. B. N. S.; RAMOS, C. S. C. B.; ABBOUD, R. S.; RIBEIRO, I. C. A.; ROPKE JUNIOR, R.; BOAVENTURA, G. T. \& CHAGAS, M. A. Influence of alpha lipoic acid supplementation on urinary bladder morphology of diabetic rats. Int. J. Morphol., 38(3):627-633, 2020.

SUMMARY: Diabetes Mellitus (DM) is a condition marked by hyperglycaemia that causes systemic complications, including urinary vesicle dysfunction due to oxidative stress. Further, antioxidants, as well as alpha lipoic acid (ALA), may be a response to this pathological condition. The present study verified the action of ALA as a supplement in ration on glycemia and urinary vesicle structures of rats induced by streptozotocin. The rats were divided into 4 groups: Control (CG), Alpha Lipoic (ALAG), Diabetic control (DCG), and the Diabetic alpha lipoic (DALAG) group. For induction, the diabetic groups were initially induced with streptozotocin (dose $60 \mathrm{mg} / \mathrm{kg}$ ). Subsequently, group glycemia was evaluated weekly. After 8 weeks, the rats were euthanized and the bladder was collected. The bladders were histologically processed and the slides were stained with Masson's Trichrome for the histomorphometry of epithelial height, connective and muscular tissue and coloration of PicroSirius Red for further analysis of collagen fibers of the bladder. The data of the glycemia demonstrated an inferior median in DALAG compared to DGC $(\mathrm{p}<0.01)$. The epithelial height and percentage of the muscle tissue were greater in DALAG compared to the DGC, but not significant. However, GDAL showed improvement in the organization of collagen fibers. In conclusion, bladder the morphology alterations caused by DM were not alleviated by the administration of ALA in 8 weeks of the experiments.

KEY WORDS: Antioxidants; Thioctic acid; Urinary; Hyperglycemia; Histological.

\section{INTRODUCTION}

Diabetes Mellitus is a metabolic disease characterized by the autoimmune destruction of the beta cells of the insulin producing pancreas. The deficiency of insulin production leads to hyperglycemia associated with systemic complications, including urinary disorders such as neuropathy, nephropathy, and bladder dysfunction (Brown et al., 2005; Jiang et al., 2008; Daneshigari et al., 2009; American Diabetes Association, 2014; Teng et al., 2014). Moreover, diabetic neuropathy may cause sequelae in the urinary tract, such as dysfunction in the urinary vesicle that affects the patient's quality of life (Arrellano-Valdez et al., 2014; Liu \& Daneshgari, 2014).

The factors described for diabetic bladder dysfunction are related to decreased bladder sensation, increased complacency and bladder capacity, detrimental contractility of the detrusor muscle, and the classic triad of diabetic cystopathy (Yuan et al., 2015). The symptoms are related to the difficulty of storage, impairing the emptying of the bladder causing urinary retention and predisposing to infections, lithiasis or renal damage (Arrellano-Valdez et al.; Wittig et al., 2019).

Furthermore, morphological changes due to diabetes may be involved in the mechanism of bladder dysfunction caused by cellular changes linked to hyperglycemia and oxidative stress (Daneshgari et al., 2009; Deli et al., 2013; Liu \& Daneshgari). Moreover, common complications in bladder dysfunction, such as increased contractility provoked by polyuria, develop compensatory bladder hypertrophy. Another mechanism involves the presence of toxic metabolites that compromise functioning, thereby decompensating the detrusor muscle and provoking bladder atonic in patients at the terminal stage (Daneshgari et al., 2006). According to the study, the pathophysiology of diabetic bladder dysfunction is associated with the ability to

\footnotetext{
${ }^{1}$ Department of Morphology, Laboratory of Cellular and Extracellular Biomorphology. Federal Fluminense University. Rio de Janeiro, Brazil.

${ }^{2}$ Department of Nutrition and Dietetics, Experimental Nutrition. Federal Fluminense University. Rio de Janeiro, Brazil.
} 
CORRÊA, L. B. N. S.; RAMOS, C. S. C. B.; ABBOUD, R. S.; RIBEIRO, I. C. A.; ROPKE JUNIOR, R.; BOAVENTURA, G. T. \& CHAGAS, M. A. Influence of alpha lipoic acid supplementation on urinary bladder morphology of diabetic rats. Int. J. Morphol., 38(3):627-633, 2020.

damage neurons, alter urothelial function, and smooth muscle architecture (Kanika et al., 2011).

Accordingly, therapeutic approaches use antioxidants as a nutritional compound in the prevention of oxidative stress in diabetes (Ustuner et al., 2010; Aybek et al., 2011). The alpha lipoic acid (ALA) is considered a potent antioxidant capable of metabolizing oxidative stress and reversing diabetic cystopathy (Jiang et al.). It acts in reduced form in the organism, with dihydrolipoic acid, being able to chelate free metals and recycle other antioxidants. However, the morphological changes in the bladder caused by a diabetic condition need to be observed.

In the present study, we observed the action of ALA supplementation on bladder histoarchitecture in streptozotocin-induced diabetes.

\section{MATERIAL AND METHOD}

The animals were approved at the Animal Use Ethics Committee of the Fluminense Federal University under protocol 799 for the accomplishment of the experiment. Rattus norvegicus rats, Albinus variety, Wistar rats kept in experiment rooms were housed in individual cages at room temperature, receiving water ad libitum and commercial ration. The animals were separated in the Control and Diabetic Control groups (CG and DCG), receiving standard feed Nuvilab and Alfa Lipoic and Diabetic Alpha Lipoic groups (ALAG and DALAG) with doses of $300 \mathrm{mg} / \mathrm{kg}$ alpha lipoic acid (R-isomer Sigma Aldrich 62320) of body weight mixed with commercial meals.

Furthermore, the diabetic groups were induced to diabetes, single intraperitoneal injection of streptozotocin (STZ, Sigma Aldrich S0130) at the dose of $60 \mathrm{mg} / \mathrm{kg}$ in Sodium Citrate buffer ( $\mathrm{pH}=4,5)$ (Kaplanoglu et al., 2013). Additionally, 3 days after the administration of STZ, the glycemia was measured in all animals using the OneTouch Ultra Perfoma (Johnson \& Johnson Company, USA) after the 10-hour fasting period, through puncture of the caudal vein. The glycemic levels equal to or greater than $270 \mathrm{mg} /$ $\mathrm{dL}$ were satisfactory for diabetic induction (Mohasseb et al., 2011). Moreover, the serum glucose levels were quantified weekly until the end of the experiment (Corrêa et al., 2019).

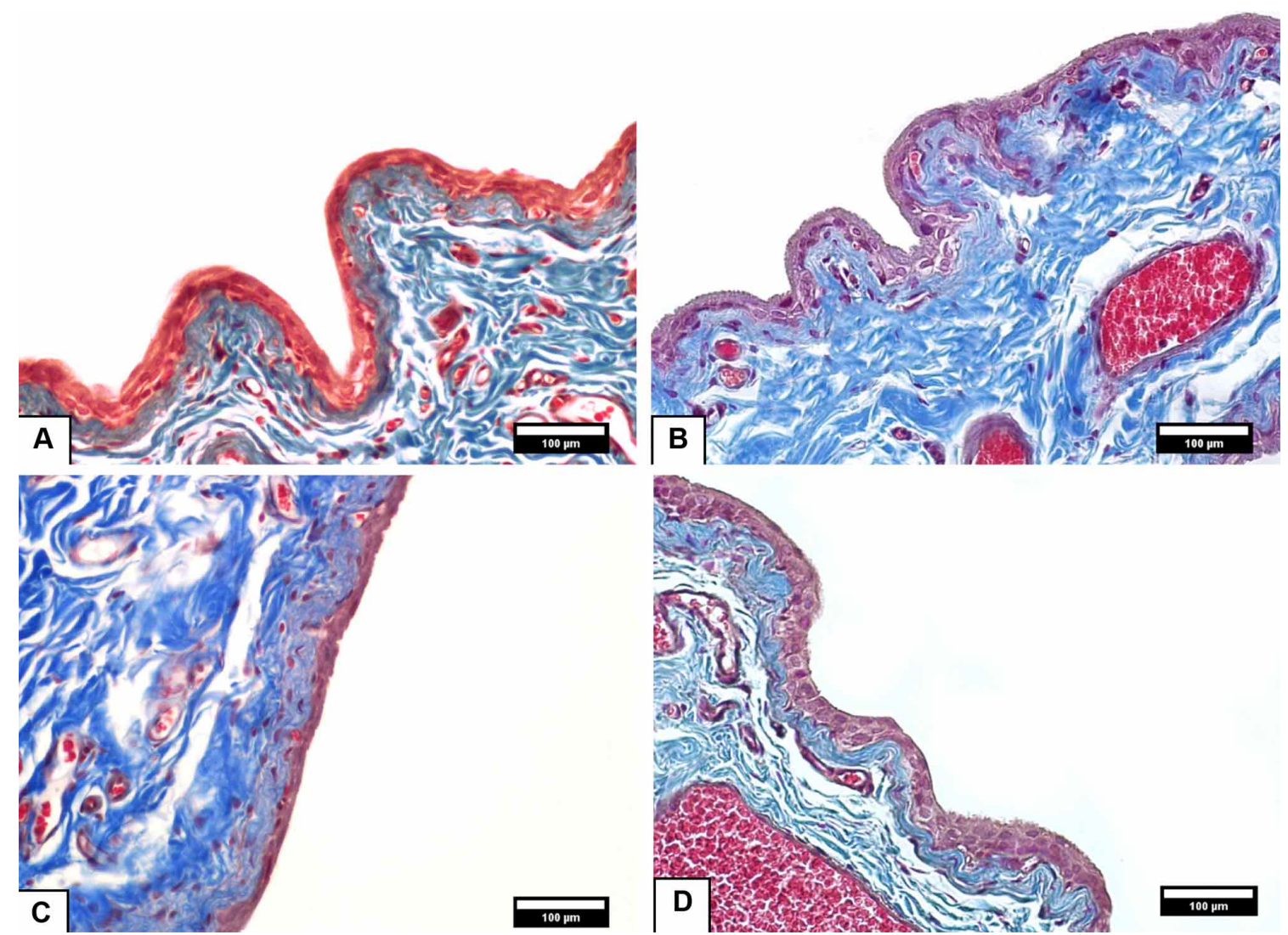

Fig. 1. Photomicrographs of the urinary vesicle stained with Masson's Trichrome to obtain epithelial height data. A-CG; B-ALAG; C-DALAG; D-DCG. Magnification 200x. 
CORRÊA, L. B. N. S.; RAMOS, C. S. C. B.; ABBOUD, R. S.; RIBEIRO, I. C. A.; ROPKE JUNIOR, R.; BOAVENTURA, G. T. \& CHAGAS, M. A. Influence of alpha lipoic acid supplementation on urinary bladder morphology of diabetic rats. Int. J. Morphol., 38(3):627-633, 2020.

After 8 weeks of the establishment of diabetes, all animals (control and diabetic group) were euthanized with xylazine and ketamine. The bladders were collected and fixed in $10 \%$ buffered formaldehyde and further processed for inclusion in paraffin. Subsequently, $5 \mu \mathrm{m}$ thick slices were obtained, and the blades were stained with the histological methods Masson's Trichrome and PicroSirius Red for polarization of collagen fibers in the 100x magnification.

The images of the urinary bladder stained with Masson trichrome were taken under optical microscope Olympus BX-51 coupled with an Olympus digital camera DP-72, with an image transferred to a microscopic field LG W1752T monitor. For the histomorphometry of bladder epithelial height, images with a 200x magnification were captured (Fig. 1). After the calibration of the Image J program (version $1.50 \mathrm{~g}$ ) using the straight tool, a line was drawn from the basal membrane to the apical cells to measure the epithelium.

Consequently, 5 bladder sections were analyzed at different points for each animal. The increasing 100x images were digitized (Fig. 2) for the quantification of connective tissue and smooth muscle tissue distribution, respectively, by stereological analysis using a 100-point grid for counting in the STEPanizer software (http://www.stepanizer.com/).

Statistical Analysis. A one-way analysis of variance (ANOVA) with the Turkey test was used to compare mean values. All analyses were availed from the Graphpad Instat software considering $\mathrm{p}<0.05$ significant.

\section{RESULTS}

Glycemia. The diabetic groups had a higher mean (above $270 \mathrm{mg} / \mathrm{dL}$ ), compared to control groups, 72-hours after induction with streptozotocin to establish Type 1 diabetes (Table I). At the end of 60 days, DALAG presented significantly less hyperglycemia than DCG.

Histomorphometry of the urinary bladder. According to Table II, the histomorphometric analysis of the epithelial height of the urinary vesicle was performed through the images stained by Masson's Trichrome (Fig. 1). The histomorphometric results showed that diabetic groups had significantly higher means compared to control groups $(\mathrm{p}<0.01)$.
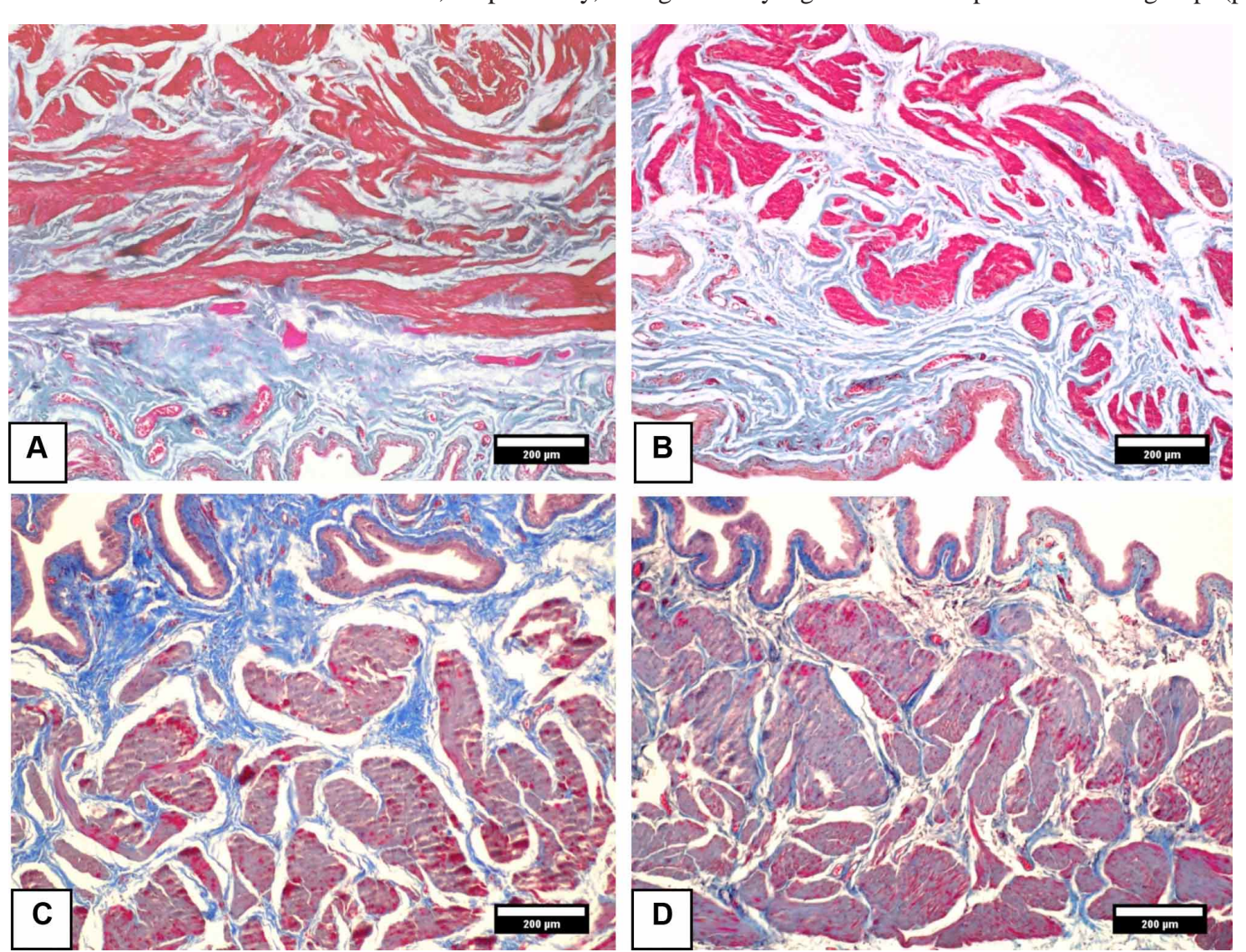

Fig. 2. Photomicrographs of the urinary vesicle stained with Masson's Trichrome for the quantitative determination of muscle and connective tissue in the bladder. A-CG; B-ALAG; C-DALAG; D-DCG. Magnification 100x. 
CORRÊA, L. B. N. S.; RAMOS, C. S. C. B.; ABBOUD, R. S.; RIBEIRO, I. C. A.; ROPKE JUNIOR, R.; BOAVENTURA, G. T. \& CHAGAS, M. A. Influence of alpha lipoic acid supplementation on urinary bladder morphology of diabetic rats. Int. J. Morphol., 38(3):627-633, 2020.

Table I. Mean and standard deviation of Glycemia after 72 hours of induction and 60 days of experimentation.

\begin{tabular}{lllll}
\hline Glycemia $(\mathrm{mg} / \mathrm{dL})$ & CG & ALAG & DCG & DALAG \\
\hline After 72h & $127.04 \pm 6.76^{\mathrm{a}}$ & $124.64 \pm 7.93^{\mathrm{b}}$ & $440.12 \pm 52.66 \mathrm{ab}$ & $429.66 \pm 62.68 \mathrm{ab}$ \\
Last Day & $118.33 \pm 9.07^{\mathrm{a}}$ & $138.33 \pm 17.78 \mathrm{~b}$ & $576.50 \pm 30.13 \mathrm{ab}^{\mathrm{c}}$ & $498.50 \pm 51.83 \mathrm{ab}^{\mathrm{c}}$ \\
\hline
\end{tabular}

The data are presented as mean \pm standard deviation. The values obtained from the ANOVA test aSignificantly different from CG; bSignificantly different from ALCG; cSignificantly different from DCG. CG - Control Group; ALAG - Alpha Lipoic Control group; DCG - Diabetic control group; DALAG - Diabetic Alpha lipoic group.

Table II. Histomorphometric results of the bladder from the control and diabetic groups.

\begin{tabular}{llllll}
\hline & CG & ALAG & DCG & DALAG & P value \\
\hline Epithelial Height $(\mu \mathrm{m})$ & $11.91 \pm 1.20$ & $12.20 \pm 1.47$ & $14.14 \pm 3.08^{\mathrm{a} b}$ & $13.98 \pm 1.62^{\mathrm{ab}}$ & 0.01 \\
Conjunctive tissue $(\%)$ & $38.70 \pm 4.76$ & $37.18 \pm 4.05$ & $29.18 \pm 4.83^{\mathrm{a} b}$ & $26.80 \pm 6.27^{\mathrm{ab}}$ & 0.01 \\
Muscle tissue $(\%)$ & $26.44 \pm 6.06$ & $22.41 \pm 4.45$ & $39.91 \pm 4.99^{\mathrm{a}} \mathrm{b}$ & $40.60 \pm 3.81^{\mathrm{ab}}$ & 0.01 \\
\hline
\end{tabular}

The data are presented as mean \pm standard deviation. The values obtained from the ANOVA test aSignificantly different from CG; bSignificantly different from ALAG; cSignificantly different from DCG. CG - Control Group; ALAG - Alpha Lipoic Control group; DCG - Diabetic control group; DALAG - Diabetic Alpha lipoic group.

The percentage of the connective tissue presented by rats fed commercial feed (CG) and supplemented with alpha lipoic acid (ALAG) were higher than DCG and DALAG. However, the percentage of muscle tissue in the diabetic groups was higher than the control groups $(\mathrm{p}<0.01)$ as shown in Figure 2. However, there was no significant difference in the parameters analyzed between the DCG and DALAG.

Polarization of collagen fibers. According to Figure 3, the collagen fibers of the experimental groups were evidenced by the polarization of the images stained with Picrosirius Red. The fibers showed reddish coloration on the dark background. Moreover, the GC and ALAG showed a continuous pattern of collagen fibers compared to DALAG and DCG. The DALAG showed a greater thickening of the collagen fibers of the urinary vesicle well detached than the DCG, which presented thinner and disorganized collagen fibers.

\section{DISCUSSION}

Hyperglycaemia from diabetes is a predominant factor for the determination of oxidative stress that contributes to the onset and progression of systemic failures through tissue damage (Parthiban et al., 1995; Rösen et al., 2001), especially in the urinary vesicle tissue (Beshay \& Carrier, 2004; Niedowicz \& Daleke, 2005). The condition may evolve to the urinary bladder dysfunction caused by diabetes, implying structural changes, which may result in decreased sensation, increased complacency and bladder capacity, and the impairment of detrusor muscle contractility (Arrellano-Valdez et al.).
In our study, tissue damage in the urinary vesicle was observed promoting a decrease in the connective tissue pattern in the diabetic groups. Accordingly, the use of antioxidants may attenuate the damage caused by the oxidative stress of diabetes that led to tissue damage (Zatalia \& Sanusi, 2013; Semeraro et al., 2019). Furthermore, Aybek et al. provided oral Vitamin E to diabetic rats for 6 weeks and observed a preventive trait on bladder damage. Despite the attributes related to antioxidants in diabetic patients, it was not possible to observe beneficial actions by supplementation with alpha lipoic acid during the period of this experiment.

The diabetic lesions observed on the urinary vesicle by histomorphometry showed increased epithelial height and muscle tissue. These data corroborate with Xiao et al. (2013), confirming the increase of smooth muscle and urothelium in diabetic rats. In a study consisting of Vitamin E use with antioxidant properties, Aybek et al. observed a decrease in epithelial cell layers and an increase of collagen in diabetic rats, especially that of the lamina propria and muscle layer in diabetic rats. In contrast, Ustuner et al. observed that Vitamin E administered intraperitoneally for 2 weeks protected the uroepithelial cells of the diabetic bladder by decreasing apoptosis. In the present study, the supplementation with alpha lipoic acid for 8 weeks did not guarantee performance regarding changes in the epithelium and muscle tissue of the bladder. However, the polarization demonstrated that the use of alpha lipoic acid in diabetes promoted the attenuation of the loss of collagen fibers in the urinary vesicle. Consequently, the supplementation with these compounds may favor the antioxidant system, being sufficient to attenuate the epithelial destruction and promote 

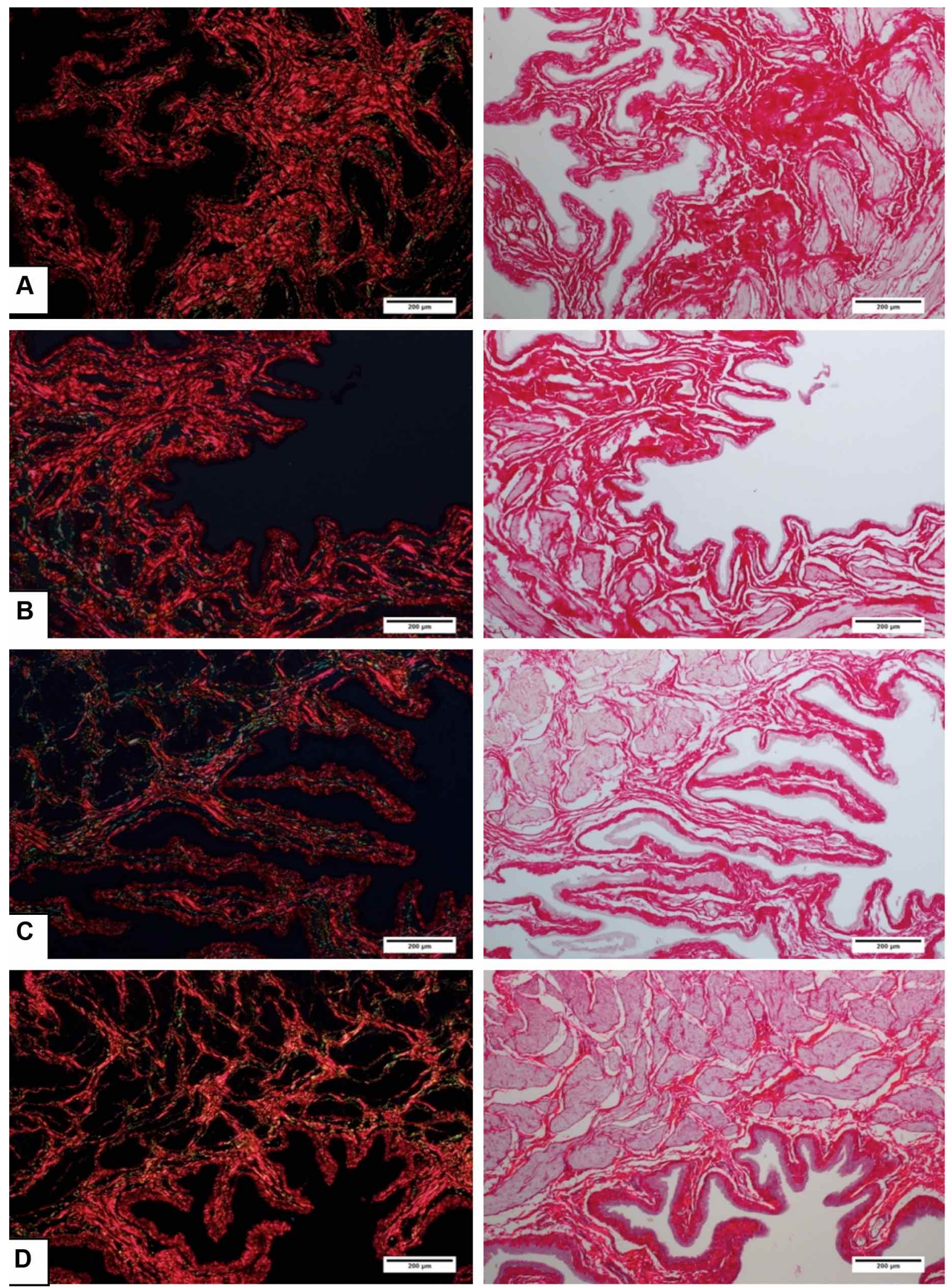

Fig. 3. Polarized photomicrographs of the urinary vesicle with reddish fibers (left) from the Picrosirius Red staining (right). DALAG (letter D) presented thicker fibers compared to DCG (letter C) close to the normal group pattern (letters A and B). ACG B-ALAG; C-DCG; D-DALAG. Color: Picrosrius Red. Magnification 100x. 
the protection of the connective tissue of the lamina propria, allowing the intervention of the diabetic complications in the urinary bladder.

Antioxidants are demonstrated as possible solutions to the systemic complications caused by oxidative stress that accompanies DM (Maritim et al., 2003; Zatalia \& Sanusi). ALA injected for 6 weeks was observed in a study by Jiang et al. acting on urinary complications playing beneficial effects on diabetic cystopathy, regardless of the attenuation of glycemia. In the present study, the glycemia presented a significant improvement by the use of the antioxidant. However, morphological changes in the bladder by histomorphometry of bladder structures were not positive at 8 weeks with added ALA supplementation the feed, allowing the period to be considered insufficient to display.

DM is a commonly observed pathology, promoting morphological and systemic complications, and the action of antioxidants can intervene in these complications. However, during the supplementation period, it was not possible to observe improvements in the morphological aspects of the urinary vesicle. The beneficial action of ALA is related to the molecular aspects improving the urodynamic mechanism. Therefore, it is possible that consumption for a prolonged period may confer action on the morphology of the bladder, thereby improving its histological structures.

\section{ACKNOWLEDGMENTS}

This study was financed in part by the Coordenação de Aperfeiçoamento de Pessoal de Nível Superior - Brazil (CAPES) - Finance Code 001 and Foundation for Research Support of Rio de Janeiro (FAPERJ).

CORRÊA, L. B. N. S.; RAMOS, C. S. C. B.; ABBOUD, R. S.; RIBEIRO, I. C. A.; ROPKE JUNIOR, R.; BOAVENTURA, G. T. \& CHAGAS, M. A. Influencia de la suplementación con ácido alfa lipoico en la morfología de la vejiga urinaria de ratas diabéticas. Int. J. Morphol.,38(3):627-633, 2020.

RESUMEN: La diabetes mellitus (DM) es una afección marcada por hiperglucemia que causa complicaciones sistémicas, incluida la disfunción de la vejiga urinaria debido al estrés oxidativo. Además, los antioxidantes, así como el ácido alfa lipoico (ALA), pueden ser una respuesta a esta condición patológica. El presente estudio verificó la acción de ALA como suplemento en la ración sobre la glucemia y las estructuras de la vejiga urinaria de ratas inducidas por estreptozotocina. Las ratas se dividieron en 4 grupos: control (CG), alfa lipoico (ALAG), control diabético (DCG) y el grupo diabético alfa lipoico (DALAG). Para la inducción, los grupos diabéticos se aplicó estreptozotocina (dosis $60 \mathrm{mg} / \mathrm{kg}$ ). Posteriormente, la glucemia grupal se evaluó semanalmente. Después de 8 semanas, las ratas se sacrificaron y se retiró la vejiga urinaria. Las vejigas se procesaron histológicamente y las muestras se tiñeron con tricromo de Masson para la histomorfometría y así evaluar la altura epitelial, el tejido conectivo y muscular. Además se tiñeron cond PicroSirius Red para un análisis posterior de las fibras colágenas de la vejiga urinaria. Los datos de la glucemia demostraron una mediana inferior en DALAG en comparación con DGC ( $p<0,01)$. La altura epitelial y el porcentaje de tejido muscular fueron mayores en DALAG en comparación con el DGC, pero no estadísticamente significativos. Sin embargo, GDAL mostró una mejora en la organización de las fibras de colágeno. En conclusión, la morfología de las alteraciones de la vejiga causada por DM no se alivió con la administración de ALA en 8 semanas de estudio.

PALABRAS CLAVE: Antioxidantes; Ácido tióctico; Urinario; Hiperglicemia; Histológico.

\section{REFERENCES}

American Diabetes Association. Diagnosis and classification of diabetes mellitus. Diabetes Care, 37 Suppl. 1:S81-90, 2014.

Arrellano-Valdez, F.; Urrutia-Osorio, M.; Arroyo, C. \& Soto-Vega, E. A comprehensive review of urologic complications in patients with diabetes. Springerplus, 3:549, 2014.

Aybek, H.; Aybek, Z.; Abban, G. \& Rota, S. Preventive effects of vitamin $\mathrm{E}$ against oxidative damage in aged diabetic rat bladders. Urology, 77(2):508.e10-4, 2011.

Beshay, E. \& Carrier, S. Oxidative stress plays a role in diabetes-induced bladder dysfunction in a rat model. Urology, 64(5):1062-7, 2004.

Brown, J. S.; Wessells, H.; Chancellor, M. B.; Howards, S. S.; Stamm, W. E.; Stapleton, A. E.; Steers, W. D.; Van Den Eeden, S. K. \& McVary, K. T. Urologic complications of diabetes. Diabetes Care, 28(1):177-85, 2005

Corrêa, L. B. N. S.; da Costa, C. A. S.; Ribas, J. A. S.; Boaventura, G. T. \& Chagas, M. A. Antioxidant action of alpha lipoic acid on the testis and epididymis of diabetic rats: morphological, sperm and immunohistochemical evaluation. Int. Braz. J. Urol., 45(4):815-24, 2019.

Daneshgari, F.; Liu, G. \& Imrey, P. B. Time dependent changes in diabetic cystopathy in rats include compensated and decompensated bladder function. J. Urol., 176(1):380-6, 2006.

Daneshgari, F.; Liu, G.; Birder, L.; Hanna-Mitchell, A. T. \& Chacko, S. Diabetic bladder dysfunction: current translational knowledge. J. Urol., 182(6 Suppl.):S18-26, 2009.

Deli, G.; Bosnyak, E.; Pusch, G.; Komoly, S. \& Feher, G. Diabetic neuropathies: diagnosis and management. Neuroendocrinology, 98(4):267-80, 2013.

Jiang, Y. J.; Gong, D. X.; Liu, H. B.; Yang, C. M.; Sun, Z. X. \& Kong, C. Z. Ability of alpha-lipoic acid to reverse the diabetic cystopathy in a rat model. Acta Pharmacol. Sin., 29(6):713-9, 2008.

Kanika, N. D.; Chang, J.; Tong, Y.; Tiplitsky, S.; Lin, J.; Yohannes, E.; Tar, M.; Chance, M.; Christ, G. J.; et al. Oxidative stress status accompanying diabetic bladder cystopathy results in the activation of protein degradation pathways. B. J. U. Int., 107(10):1676-84, 2011.

Kaplanoglu, G. T.; Bahcelioglu, M.; Gozil, R.; Helvacioglu, F.; Buru, E.; Tekindal, M. A.; Erdogan, D. \& Calguner, E. Effects of green tea and vitamin $\mathrm{E}$ in the testicular tissue of streptozotocin-induced diabetic rats. Saudi Med. J., 34(7):734-43, 2013. 
Liu, G. \& Daneshgari, F. Diabetic bladder dysfunction. Chin. Med. J. (Engl.), 127(7):1357-64, 2014.

Maritim, A. C.; Sanders, R. A. \& Watkins 3rd, J. B. Diabetes, oxidative stress, and antioxidants: a review. J. Biochem. Mol. Toxicol., 17(1):2438, 2003.

Mohasseb, M.; Ebied, S.; Yehia, M. A. H. \& Hussein, N. Testicular oxidative damage and role of combined antioxidant supplementation in experimental diabetic rats. J. Physiol. Biochem., 67(2):185-94, 2011.

Niedowicz, D. M. \& Daleke, D. L. The role of oxidative stress in diabetic complications. Cell Biochem. Biophys., 43(2):289-330, 2005.

Parthiban, A.; Vijayalingam, S.; Shanmugasundaram, K. R. \& Mohan, R. Oxidative stress and the development of diabetic complications-Antioxidants and lipid peroxidation in erythrocytes and cell membrane. Cell Biol. Int., 19(12):987-93, 1995.

Rösen, P.; Nawroth, P. P.; King, G.; Möller, W.; Tritschler, H. J. \& Packer, $\mathrm{L}$. The role of oxidative stress in the onset and progression of diabetes and its complications: a summary of a congress series sponsored by UNESCO-MCBN, the American Diabetes Association and the German Diabetes Society. Diabetes Metab. Res. Rev., 17(3):189-212, 2001.

Semeraro, F.; Morescalchi, F.; Cancarini, A.; Russo, A.; Rezzola, S. \& Costagliola, C. Diabetic retinopathy, a vascular and inflammatory disease: therapeutic implications. Diabetes Metab., 45(6):517-27, 2019.

Teng, J.; Dwyer, K. M.; Hill, P.; See, E.; Ekinci, E. I.; Jerums, G. \& MacIsaac, R. J. Spectrum of renal disease in diabetes. Nephrology (Carlton), 19(9):528-36, 2014.

Ustuner, M. C.; Kabay, S.; Ozden, H.; Guven, G.; Yucel, M.; Olgun, E. G.; Ustuner, D.; Unal, N \& Degirmenci, I. The protective effects of vitamin e on urinary bladder apoptosis and oxidative stress in streptozotocininduced diabetic rats. Urology, 75(4):902-6, 2010.

Wittig, L.; Carlson, K. V.; Andrews, J. M.; Crump, R. T. \& Baverstock, R. J. Diabetic bladder dysfunction: a review. Urology, 123:1-6, 2019.

Xiao, N.; Wang, Z.; Huang, Y.; Daneshgari, F. \& Liu, G. Roles of polyuria and hyperglycemia in bladder dysfunction in diabetes. J. Urol., 189(3):1130-6, 2013.

Yuan, Z.; Tang, Z.; He, C. \& Tang, W. Diabetic cystopathy: a review. J. Diabetes, 7(4):442-7, 2015.

Zatalia, S. R. \& Sanusi, H. The role of antioxidants in the pathophysiology, complications, and management of diabetes mellitus. Acta Med. Indones., 45(2):141-7, 2013.
Corresponding author:

Prof. Dr. Mauricio Alves Chagas

Federal Fluminense University

Rua Prof Hernani de Melo

101 - São Domingos

Niterói-Rio de Janeiro

BRAZIL

Email: chagas.m@gmail.com

Received: 19-08-2019

Accepted: 06-11-2019 